\title{
MONOCLONAL ANTIBODIES TO HORDEIN POLYPEPTIDES
}

\author{
by
}

\author{
STEVEN E. ULLRICH ${ }^{1,2)}$, ULLA RASMUSSEN ${ }^{1,3)}$, GUNILLA HØYER-HANSEN ${ }^{1)}$, \\ and ANDERS BRANDT ${ }^{1)}$
}

\author{
"Department of Physiology, Carlsberg Laboratory, \\ Gamle Carlsberg Vej 10, DK-2500 Copenhagen Valby \\ ${ }^{2}$ Washington State University, Dept. of Agronomy and Soils, \\ Pullman, WA 99164-6420, USA \\ and \\ ${ }^{3}$ Carlsberg Research Laboratory, Department of Biotechnology, \\ Gamle Carlsberg Vej 10, DK-2500 Copenhagen Valby
}

\begin{abstract}
Keywords: Barley, hordein mutants, immunoblotting, SDS-PAGE, storage polypeptides, homology, screening
\end{abstract}

\begin{abstract}
Monoclonal antibodies to hordein polypeptides have been produced and characterized. All antibodies reacted with more than one polypeptide, indicating that different hordein polypeptides have common epitopes. Of the seventeen isolated hybridoma lines, six secreted antibodies which reacted both with B- and C-hordein, five recognized only B-hordein and one secreted antibodies specific for C-hordein polypeptides. Two clones produced antibodies to an unidentified polypeptide doublet with an apparent molecular weight of $43 \mathrm{kD}$. These two polypeptides have at least one epitope in common with B-hordein polypeptides and are not extractable in water but in alcohol. They are not visible by Coomassie blue staining.

The mutant M56 fails to synthesize B-hordein polypeptides due to a major deletion. It contains polypeptides in the B-hordein region of the gel, which have epitopes recognized by the B-hordein antibodies, but are different from B-hordeins. The $43 \mathrm{kD}$ hordein doublet was more abundant in the mutant than in the wild-type endosperm, suggesting that these polypeptides like the $\mathrm{C}$-hordein polypeptides are synthesized in larger amounts as a consequence of the absent B-hordein polypeptide synthesis. Mutant 1508 which has an impaired synthesis of both B- and C-hordein polypeptides was also found to be defective in the synthesis of the $43 \mathrm{kD}$ polypeptide doublet. It was shown that immunofluorescent techniques may be of practical importance to identify mutants with elevated or reduced amounts of specific hordein polypeptides. Due to the higher sensitivity compared to SDS-PAGE, immunoblotting can be a useful tool for genotype identification in breeding programmes.
\end{abstract}

\section{INTRODUCTION}

One objective in barley breeding has been to improve the nutritional quality through increasing the amount of lysine in the seed. The high-lysine genes usually decrease the synthesis of the lysine deficient storage protein, hordein $(4,11,29,33)$. Hordein polypeptides are synthesized during endosperm development, deposited in protein bodies and may account for half of the total endosperm protein at seed maturity $(7$,

Abbreviations: $\mathrm{CM}=$ Carlsberg Monoclonal; FITC = fluorescein isothiocyanate; $\mathrm{Ig}=\mathrm{immunoglobulin} ; \mathrm{kD}=\mathrm{kilodalton}$; $\mathrm{MAb}=$ monoclonal antibody; $\mathrm{p}=$ protein $; \mathrm{PAGE}=$ polyacrylamide gel electrophoresis; $\mathrm{SDS}=$ Sodium dodecyl sulphate; Tris = tris-(hydroxymethyl)-aminomethane. 
8,30 ). The hordein can be separated into B-, Cand D-polypeptides with increasing molecular weight, coded for by the genes Hor2, Hor 1 and Hor 3 , respectively, on chromosome $5(2,13,35$, $42,43)$. Each locus is considered to contain several structural genes, each coding for one polypeptide within the group. The Hor 2 locus is the most complex with 15-20 members. Hor 1 with 3-6 members and Hor 3 with only a few (5, 14, 19, 37). The B-hordein polypeptides are by far the most abundant and may constitute $70 \%$ of total hordein, but the proportion of the three groups in the endosperm is highly influenced by nitrogen fertilization (21). The C-hordein polypeptides are preferentially synthesized when the level of nitrogen in the soil is high. Differences in composition among the groups also exist, the B-hordein polypeptides contain cysteine and methionine, whereas C-hordein appears to be devoid of these amino acids (40).

Our understanding of storage protein gene regulation is fragmentary and only beginning to be accessible to analysis following the isolation and characterization of two storage protein genes from barley $(5,20)$. The primary structure of the two genes have provided the first complete amino acid sequences of two $B 1$ hordein polypeptides and based on limited amino acid sequence information derived from direct and cDNA nucleotide sequences a model has been proposed to describe the primary structure homologies and differences among the hordein polypeptides (32). It is thought that the B- and C-hordein polypeptides have a region in common which is composed of repeated blocks of glutamine and proline residues. In the two known B-hordein polypeptides this region is localized in the $\mathrm{NH}_{2}$-terminal third of the molecule. The remaining part appears to be unique to the B-hordein polypeptide and amino acid substitutions in this region appear to be the major source for the charge polymorphism observed among the B-hordein polypeptides (5, 36). In contrast, the glutamine + proline rich region occupies most of the C-hordein polypeptides while only short regions in the $\mathrm{NH}_{2}$ - and $\mathrm{COOH}$-terminal part are unique. The glutamine + proline rich region in these two groups of polypeptides are homologous and amino acid sequences deduced from cDNA clones suggest that $\mathrm{C}$-hordein polypeptides even have glutamine + proline blocks identical to those found in B-hordein $(19,37)$.

The high lysine mutant M56 (hor2ca) in c.v. Carlsberg II is characterized by a drastic reduction in B-hordein and an increase in C-hordein polypeptide synthesis (33). DoLl (11) concluded that this alteration in protein synthesis was due to a nearly non-functional mutant allele of Hor2. Further analysis by KREIS et al. (31) indicated that at least $85 \mathrm{kbp}$ of DNA were deleted from the Hor 2 locus in this mutant. In another high-lysine mutant M1508 (lys3a) the amounts of essentially all of the B- and Chordeins are reduced, whereas the $\mathrm{D}$-hordein polypeptides are unaffected $(7,33)$. In both these mutants the high lysine phenotype is due to an increase in albumin/globulin polypeptides, and in the case of M1508 also in free amino acids. The high lysine mutants also have an impaired starch synthesis and thus lower grain yield. Maintaining grain yield and increasing the amount of lysine has thus far been an unfulfilled goal for plant breeders. It may well be that our knowledge of gene expression in the endosperm and of the primary structure of the polymorphic hordein polypeptides are too limited to design rational selection and breeding methods to obtain the wanted high lysine, high yielding barley variety. A help in selecting the right barley mutants would be to produce monoclonal antibodies which recognize different domains on the polypeptides.

The objective of this study was to produce and characterize monoclonal antibodies to hordein polypeptides. The antibodies were used to provide further information on homologies and differences among the hordein polypeptides, and to try out the potential for identifying mutants with the aid of fluorescent labelled antibodies on thin sections of barley seeds.

\section{MATERIALS AND METHODS}

\subsection{Antigen preparations}

Seventy gr Bomi barley flour was pre-extracted with $50 \%(\mathrm{v} / \mathrm{v})$ propanol-2-ol at $20^{\circ} \mathrm{C}$ for 1 hour and centrifuged at $10,400 \times \mathrm{g}$ for $10 \mathrm{~min}$. The pellet was re-extracted with $50 \%(\mathrm{v} / \mathrm{v})$ propan $2-\mathrm{ol}, 2 \%(\mathrm{v} / \mathrm{v}) \beta$-mercaptoethanol at 
Table I. Injections of C-hordein preparation prior to the fusion

\begin{tabular}{cc}
\hline $100 \mu \mathrm{g}$ in FCA & Day 0 \\
$200 \mu \mathrm{g}$ in FIA & Day 21 \\
$20 \mu \mathrm{g}$ in FIA & Day 42 \\
Tailbleeding & Day 47 \\
$40 \mu \mathrm{g}$ in $\mathrm{H}_{2} \mathrm{O}$ & Day 63 \\
$200 \mu \mathrm{g}$ in $\mathrm{H}_{2} \mathrm{O}$ & Day 64 \\
$400 \mu \mathrm{g}$ in $\mathrm{H}_{2} \mathrm{O}$ & Day 67 \\
$300 \mu \mathrm{g}$ in $\mathrm{H}_{2} \mathrm{O}$ & Day 68 \\
Fusion & Day 70 \\
\hline
\end{tabular}

FCA: Freund's complete adjuvant

FIA: Freund's incomplete adjuvant

$60{ }^{\circ} \mathrm{C}$ for 1 , hour. Following centrifugation 3 vol water was added to the supernatant and the mixture stored at $-80{ }^{\circ} \mathrm{C}$ for 0.5 hour. The precipitate was recovered by centrifugation, the pellet redissolved in $45 \mathrm{ml} 6 \mathrm{M}$-urea, $2 \%(\mathrm{v} / \mathrm{v})$ $\beta$-mercaptoethanol and dialysed against $6 \mathrm{M}$ urea. B-hordein polypeptides were precipitated out of the solution by lowering the urea concentration to $1.5 \mathrm{M}$, and $\mathrm{C}$-hordein polypeptides were precipitated by adjusting the supernatant to $4 \mathrm{M}-\mathrm{NaCl}$. This enriched $\mathrm{C}$-hordein fraction was used as the antigen injected into mice to produce the antibodies.

Total hordein was extracted from barley grain flour with $55 \%(\mathrm{v} / \mathrm{v})$ propan-2-ol, $2 \%(\mathrm{v} / \mathrm{v})$ $\beta$-mercaptoethanol. Hordein polypeptides were precipitated by dialysis against water and recovered by centrifugation.

Sequential extraction of albumin and globulin were done by extraction of barley grain flour with water followed by $0.5 \mathrm{M}-\mathrm{NaCl}$. The polypeptides were precipitated by $10 \%(\mathrm{v} / \mathrm{v})$ trichloracetic acid and recovered by centrifugation. The pellets were washed in acetone before redissolving for electrophoresis.

Figure 1. Antigen preparations

Typical pattern of reduced and alkylated hordeins Coomassie-stained after SDS-PAGE, cv. Bomi (34) (lane 1).

Enriched C-hordein preparation obtained by salt fractionation after alcohol extraction, cv. Bomi (lane 2). This preparation was injected into mice for antibody production.
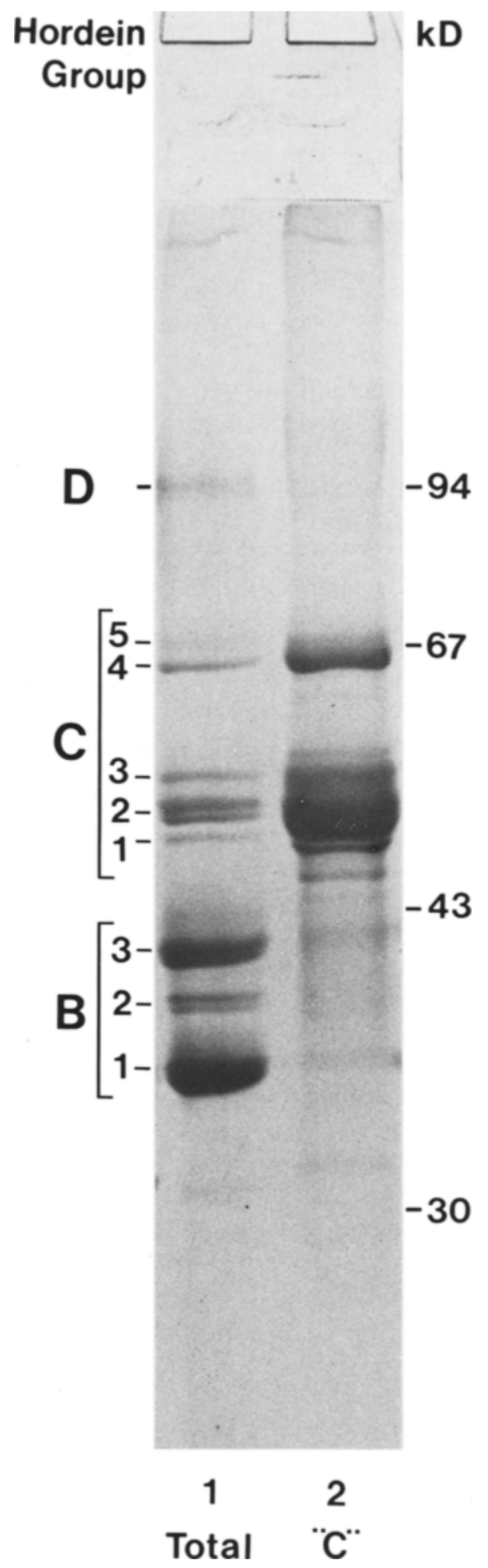
Samples for electrophoresis were dissolved and heated to $90^{\circ} \mathrm{C}$ for $3 \mathrm{~min}$ in $0.1 \mathrm{M}$-Tris- $\mathrm{HCl}$ pH 8.8, $0.25 \mathrm{M}$-sucrose, $0.05 \%(\mathrm{w} / \mathrm{v})$ bromphenol blue, $2 \%(\mathrm{w} / \mathrm{v})$ SDS, $5 \mathrm{~mm}$-dithiothreiotol. Iodoacetamide was added to $50 \mathrm{~mm}$ and the samples left at room temperature for $15 \mathrm{~min}$ before loading onto the gel.

\subsection{Immunization}

Female mice (Balb/c strain, Bomholtgaard, Ry, Denmark) were injected intraperitonally with a hordein preparation (cv. Bomi) enriched in $\mathrm{C}$-hordeins. The mouse received 7 injections in total and the first injection was given when the mouse was 5-6 weeks old. The immunization schedule is shown in Table I.

\subsection{Fusion}

The fusion procedure was essentially as described by FAzeKas DE ST. Groth and SCHEIDEGGER (15). The immunized mouse was killed and $9.6 \times 10^{7}$ spleen cells were fused with $4.3 \times 10^{7}$ myeloma cells (X63-Ag 8.6.5.3). The myeloma line and the resulting hybridoma lines were grown in Dulbeccos modified Eagles' Medium (DMEM) supplemented with $1 \mathrm{~mm}$ sodium pyruvate, 100 units penicillin-streptomycin/ml, 2 mM-glutamine, $0.05 \mathrm{~mm}$-2-mercaptoethanol and $10 \%(\mathrm{v} / \mathrm{v})$ fetal calf serum. During fusion $6 \mathrm{ml}$ of $50 \%(\mathrm{w} / \mathrm{v})$ polyethylene glycol 4000 (Merck, cat. no. 9727) in $10 \mathrm{mm-}$ sodium phosphate, $137 \mathrm{~mm}-\mathrm{NaCl}, 5 \mathrm{~mm}-\mathrm{KCl}$, $10 \mathrm{~mm}$-glucose, $10 \mathrm{mg}$ phenol red was added. The fused cells were resuspended in $48 \mathrm{mls}$ of HAT-media (complete DMEM supplemented with 0.1 mM-hypoxanthine, $4 \times 10^{-7} \mathrm{M}$ aminopterin, $1.6 \times 10^{-5}$ M-thymidine) before plating out in 10 microtest plates (Nunc).

The hybridoma clones formed were transferred to 24 well Multidishes (Nunc) and aminopterin was omitted from the media. The clones were screened for antibody production by immunoblotting, when confluent growth was apparent. The antigen was total hordeins extracted from the cultivar Bomi.

Cells secreting antibodies were cloned by limited dilution (41) employing $10^{4}$ macrophages per well. The selected clones were grown in complete DMEM in $260 \mathrm{ml}$ tissue culture flasks and the hybridoma supernatant was collected and used directly for assays or pooled and frozen for later use.

The class of secreted antibodies was determined by an Ouchterlony double diffusion test (26).

\subsection{SDS-PAGE and electrophoretic blotting procedure}

Electrophoresis in SDS was performed in either $11-15 \%$ gradient or $11 \%$ gels (9). Immediately after completion of the electrophoretic run the polypeptides were transferred from the SDS gel to nitrocellulose filters (Millipore HAHY, pore size $0.45 \mu \mathrm{m}$ ) using $125 \mathrm{~mm}$-Tris, 192 mM-glycine, $\mathrm{pH} 8.9,20 \%(\mathrm{v} / \mathrm{v})$ methanol as the transfer buffer $(27,47)$. The electrotransfer was performed for $2.5 \mathrm{hrs}$ at $2 \mathrm{~A}$ and $60 \mathrm{~V}$ in a chromatography chamber with electrodes of acid-hardened stainless steel. The chromatography chamber was placed in ice during the electrotransfer. Immediately after transfer the nitrocellulose filters were cut into strips and kept in the dark at room temperature until used for immunoblot assays. Reference strips were stained with amido black $(0.1 \%$ in $45 \%$ methanol $/ 10 \%$ acetic acid) and destained in methanol/water/acetic acid $(2 \mathrm{v} / 2 \mathrm{v} / 0.4 \mathrm{v})$. SDSgels were stained with Coomassie blue. For calibration of molecular weights the following marker proteins were used: phosphorylase $b, 94$ $\mathrm{kD}$; bovine serum albumin, $67 \mathrm{kD}$; ovalbumin, $43 \mathrm{kD}$; carbonic anhydrase, $30 \mathrm{kD}$; soybean trypsin I, $20.1 \mathrm{kD}$; $\alpha$-lactoglobulin, $14.4 \mathrm{kD}$ (Pharmacia AB, Uppsala, Sweden).

\subsection{Immunoblot assay}

The nitrocellulose filter strips with the immobilized antigens were soaked for one hour at $37{ }^{\circ} \mathrm{C}$ in $10 \%$ newborn calf serum (NBC) in phosphate buffered saline (PBS) pH 7.2. They were then washed with three changes of PBS and incubated for 2 hours at $37{ }^{\circ} \mathrm{C}$ with hybridoma supernatant. After washing five times in $1 \%$ bovine serum albumin in PBS, the strips were incubated for 1-2 hours with peroxidase-conjugated rabbit immunoglobulins to mouse im- 


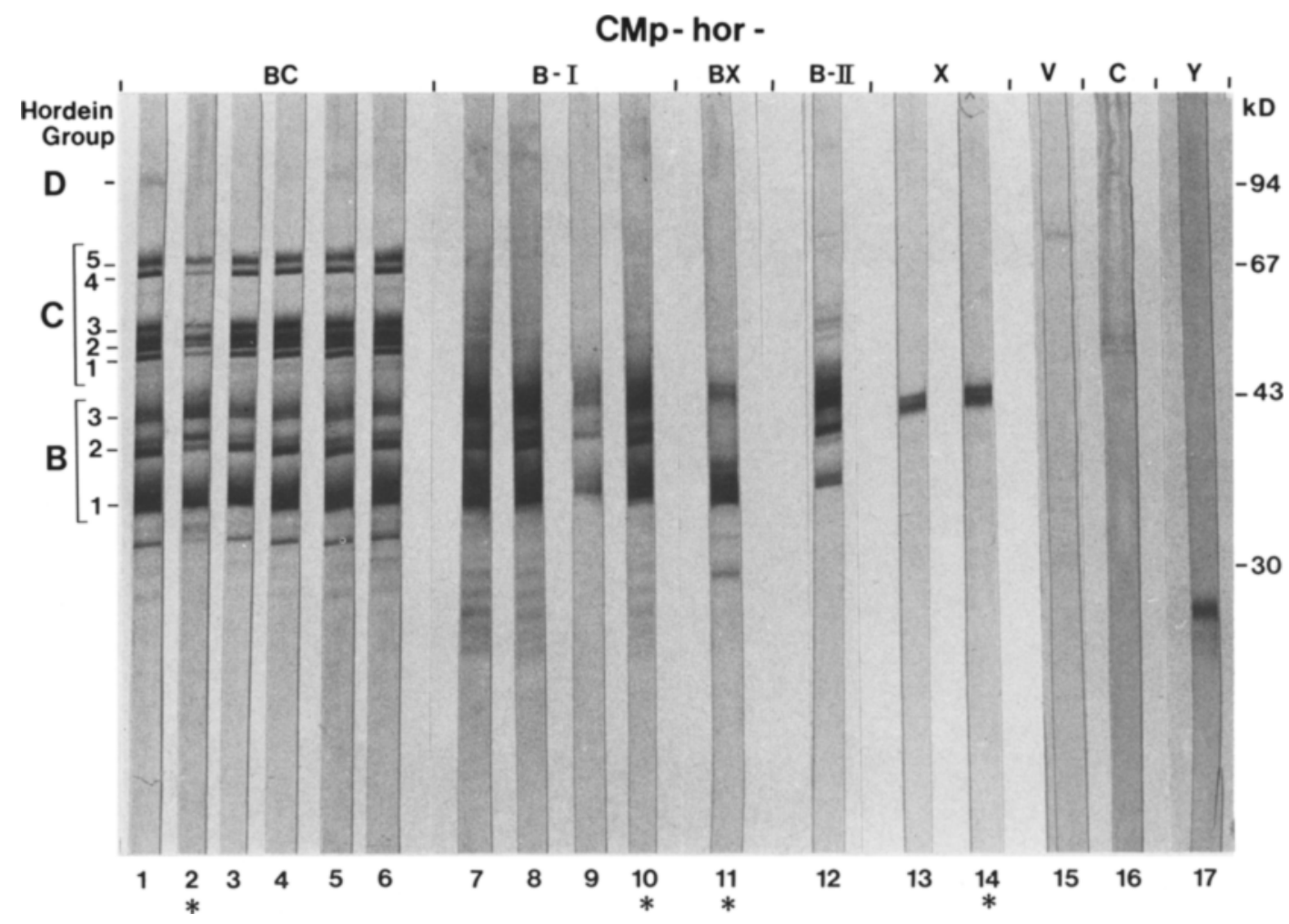

Figure 2. Specificity of antibodies obtained.

Immunoblot assays showing the specificities of the obtained MAb. Six CMpBChor antibodies react with essentially all B-and C-hordeins (strips 1-6); four $\mathrm{CMpBhorl}$ and one $\mathrm{CMpBhorlI}$ with various $\mathrm{B}$-hordeins (strips 7-10, 12); CMpBXhor and $\mathrm{X}$ hor with $\mathrm{B}$ - and/or " $\mathrm{X}$ "-hordeins (strips 11, 13, 14); $\mathrm{CMpV}, \mathrm{C}$, and $\mathrm{Y}$ hor with apparently only "V"-, C-, and "Y"-hordeins, respectively (strips 15-17). "V", "X" and "Y" are temporary designations as these are heretofore unidentified polypeptides.

* Cell lines cloned by limited dilution.

munoglobulins (Dako immunoglobulins A/S cat. no. P161). The secondary antibody was diluted 500-fold with $10 \%$ NBC in PBS. The strips were washed five times with PBS before the colour was developed with the aid of 3amino-9-ethylcarbazole (22).

\subsection{Immunofluorescence labelling}

Thin sections of Carlsberg II and its B-hordein deficient mutant Risø 56 and Bomi and its hordein deficient mutant 1508 were reacted with fluorescein isothiocyanate (FITC)-labelled CMpBhorl:1. This B-hordein specific monoclonal antibody is of the IgG class and the conjugation to FITC was carried out as de- scribed by RASMUSSEN (39). Fixation of the sectioned kernels was omitted since the hordein polypeptides are essentially water insoluble. The thin sections were observed microscropically at 2.5 times magnification.

\section{RESULTS}

\subsection{Production of monoclonal antibodies to hordeins}

The antigen preparation used to inject mice for antibody production was an enriched $\mathrm{C}$ hordein fraction from Bomi barley flour (Figure 1 , lane 2). This preparation contained in addition some B-hordein polypeptides (Figure 1, lane 1 vs. lane 2 ). Since a single spleen cell, only 


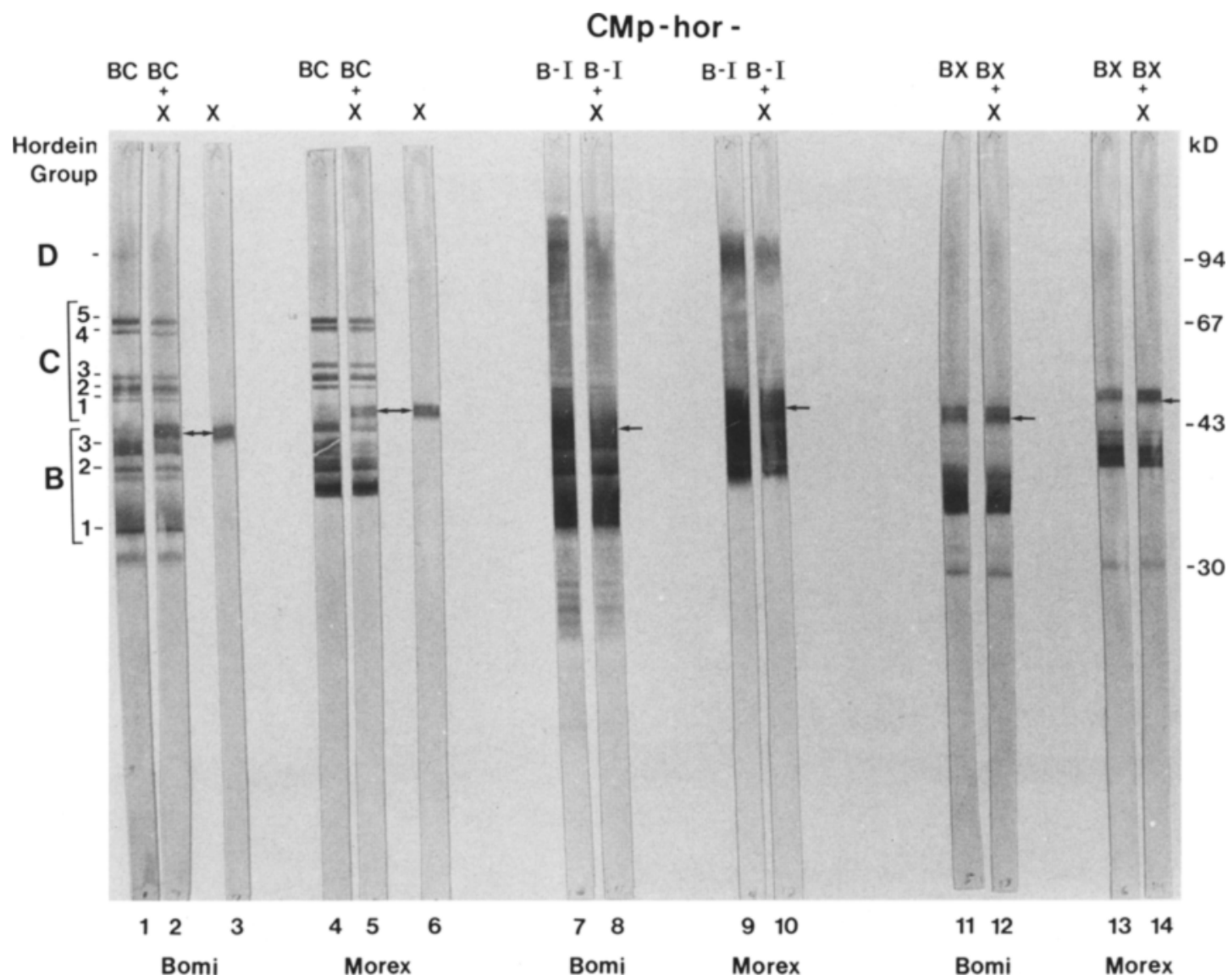

Figure 3. Immunoblot assay to determine which hordeins have common epitopes with the $\mathrm{X}$ doublet.

Four MAb's are represented here in single and double antibody immunoblot assays to illustrate their specificities. Total hordein extract, $\mathrm{cv}$. Bomi or Morex was the antigen on the nitrocellulose strips. CMpXhor is specific to an apparently heretofore unidentified polypeptide doublet (strips 3,6). The "X"-hordein shares a common determinant (epitope) with at least B-hordein determined by CMpBXhor (strips 11-14). The other MAb's with B-hordein specificity (CMpBChor and CMpBhorl) do not recognize the same epitopes as CMpXhor (strips 1, 2, $4,5,7-10)$.

has the genetic coding capacity for one antibody reacting with one epitope (antigenic determinant) the antigen preparation need not be pure to obtain antibodies to single epitopes.

Seventeen hybridoma lines secreting antibodies to epitopes on eight different groups of hordein polypeptides were obtained from one fusion. The specificity of the antibodies was tested with immunoblot assays with total hordein extract from Bomi as the antigen (Figure 2). A CMpBChor antibody reacts with a common epitope in the polypeptides of all of the major B- and C-hordein polypeptides (Figure 2, strips 1-6). CMpBhorI and $\mathrm{CMpBhorII}$ antibodies react with all major B-hordein polypeptides (Figure 2, strips 7-10 and 12, respectively). $\mathrm{CMpBXhor}$ and $\mathrm{CMpXhor} \mathrm{antibodies} \mathrm{react}$ with $B$ - and " $X$ "-hordein polypeptides and " $X$ "polypeptides, respectively (Figure 2, strips 11 and 13,14 , respectively). CMpVhor, CMpChor, and $\mathrm{CMpYhor}$ antibodies react with apparently only "V"- and C-hordein and "Y"-polypeptides, respectively (Figure 2, strips 15, 16, 17, respectively). " $V$ ", " $X$ " and " $Y$ " are unidentified polypeptides that are not stainable with Coomassie-blue. The four lines marked with an 


\section{CMpBC hor :}

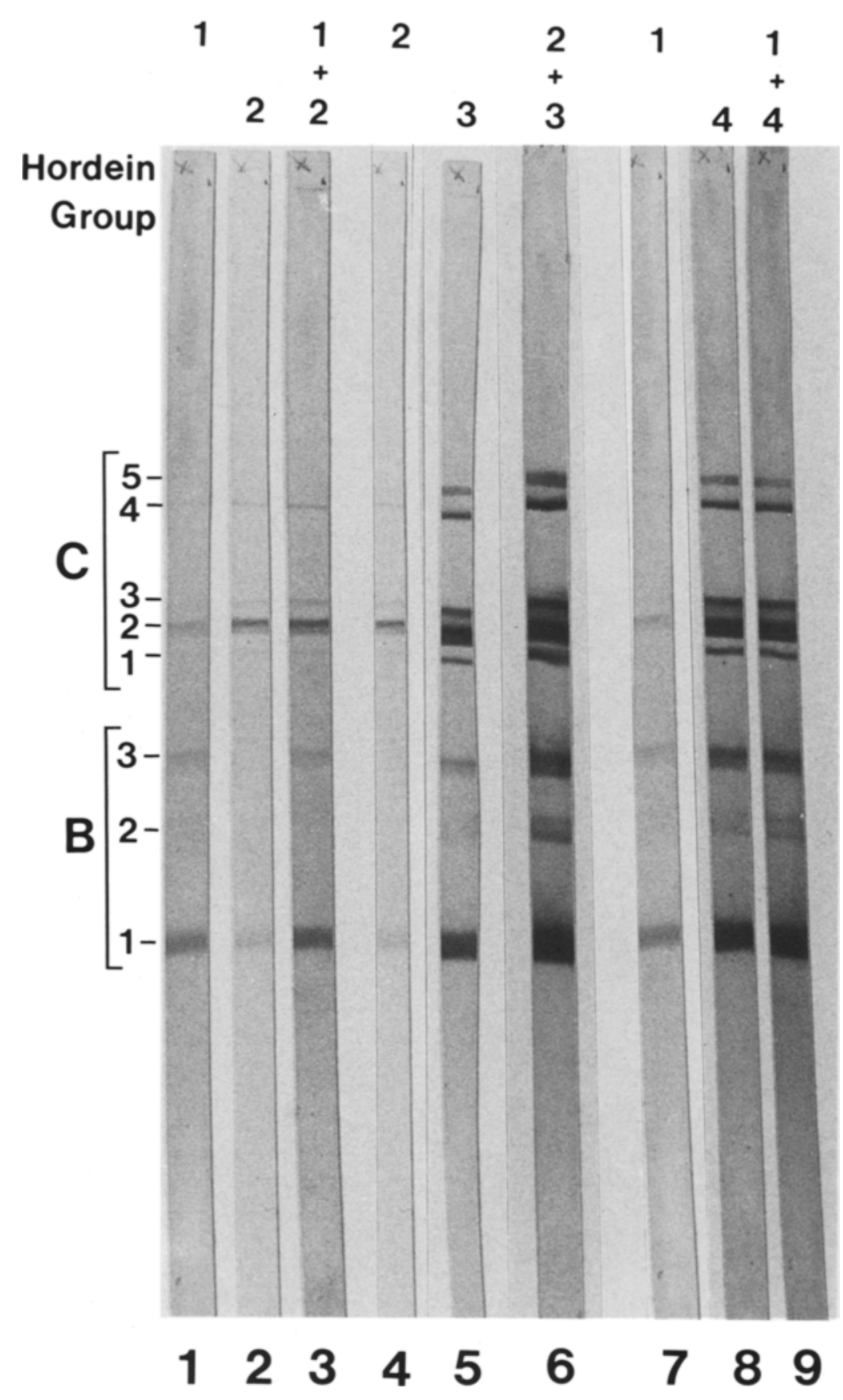

Figure 4. Epitope specificity of $\mathrm{CMpBChor}$ antibodies.

A very dilute preparation ( $2 \mu \mathrm{g}$ protein $/ \mathrm{cm}$ ) of total hordein extract $\mathrm{cv}$. Bomi was probed with saturating amounts of different MAb's of the BC-hordein type singly (strips 1, 2, 4, 5, 7, 8) and in pairs (strips 3,6,4). 


\section{CMp-hor -}

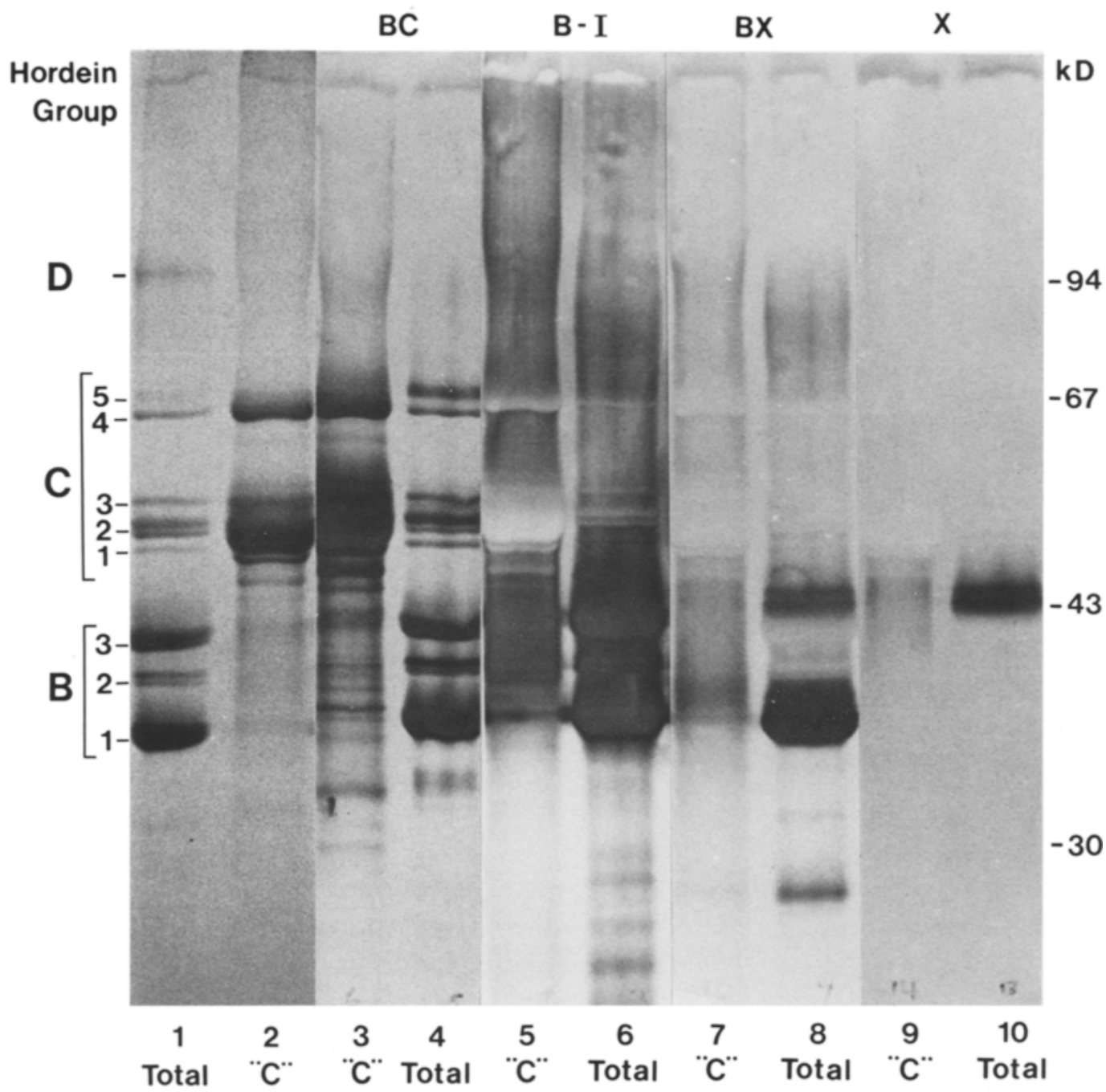

Figure 5. Antigenicity of hordeins.

Enriched C-hordein (injected into mice for antibody production) and total hordein preparation, cv. Bomi, Coomassie-stained after SDS-PAGE (lanes 2 and 1, respectively). A series of this pair was transferred to nitrocellulose filters and probed with four different MAb's (lanes 3-10).

asterisk in Figure 2 were cloned by limited dilution and secrete antibodies of the IgG class as determined by Ouchterlony tests. Immunoblot assays with two cultivars (Bomi and Morex) using single and combinations of two MAb's, showed that CMpBChor and CMpBhor do not recognize the " $X$ "-polypeptide doublet (Figure 3, strips 1-10), but that CMpBXhor does
(Figure 3, strips 11-14). The recognition of more than one polypeptide by these monoclonal antibodies is consistent with the finding that $\mathrm{B}$ - and C-hordein polypeptides contain common amino acid sequences $(5,19,20,37)$.

\subsection{Epitope specificity}

The most frequently produced antibody was 


\section{CMpBChor :}

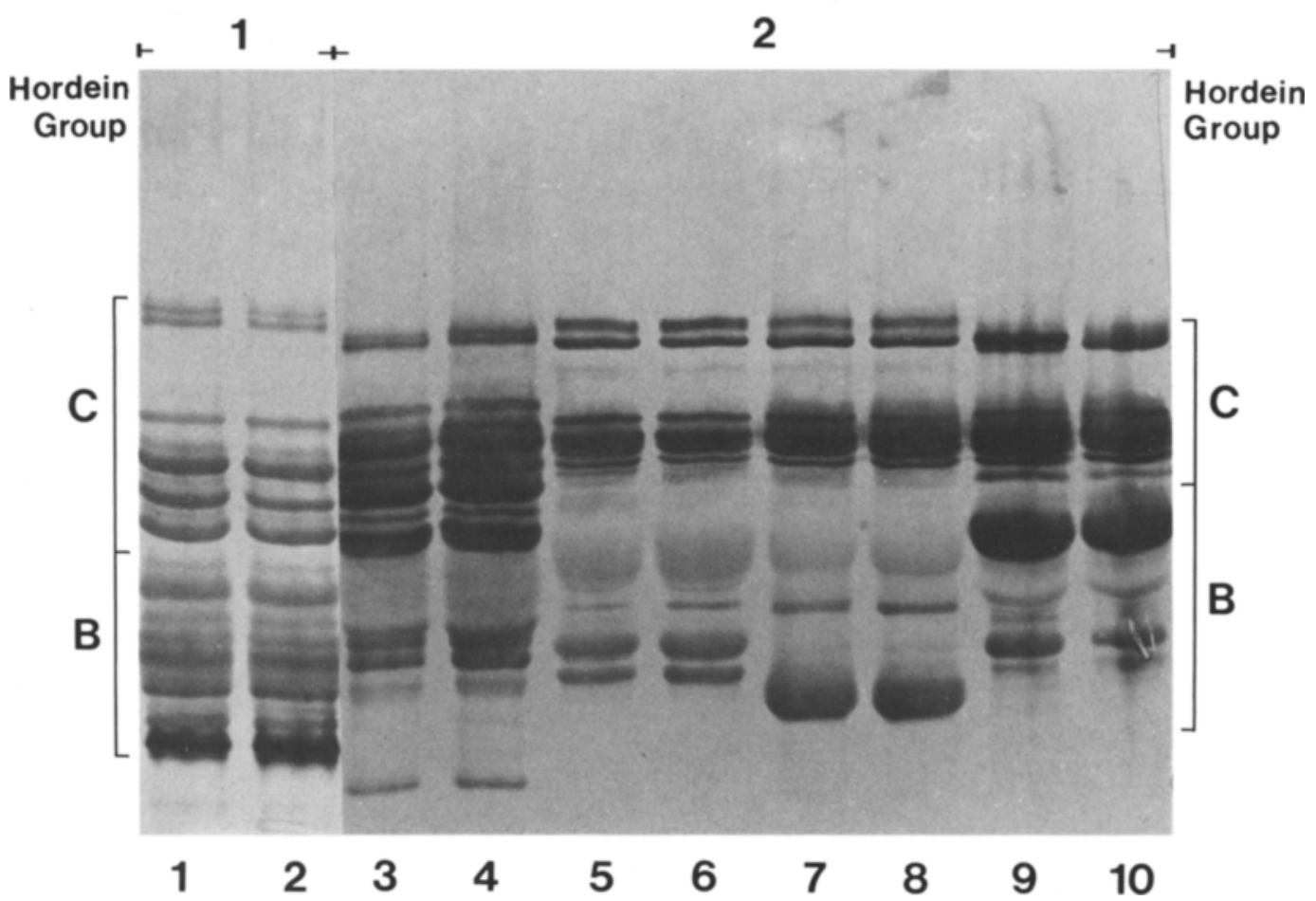

Figure 6. Detection of hordein polymorphism with MAb's.

Immunoblot assays with total hordein extracts of several barley cultivars as antigens probed with two different BC-hordein MAb's. The hordein polypeptides of Sonja (lane 1) and Igri (lane 2) were probed with CMpBChor:1. Igri, Sonja, Corgi, Doublet, Apex, Atem, Golden Promise and Maris Otter were probed with CMpBChor:2 (lanes 3-10, respectively).

of the $\mathrm{CMpBChor}$ type, but these antibodies showed considerable variation in immunoblot assays. Even though the same polypeptides are recognized, some of the $\mathrm{BC}$-hordein antibodies seem to react with different antigenic sites, i.e. the epitope specificity varies (28). To illustrate this, BC-hordein antibodies derived from four different hybridoma cell lines were tested singly and in pairs against a very low concentration of total hordein antigen in immunoblot assays, (Figure 4). The intensity of the reacting bands using both CMpBChor: 1 and 2 is increased and thus these antibodies have different epitope specificities (Figure 4, strips 1-3) as do CMpBChor:2 and 3 (Figure 4, strips 4-6), whereas $\mathrm{CMpBChor:1}$ and 4 probably react with the same epitope. The difference in epitope specificity of CMpBChor: 1 and 2 is also evident in Figure 6, lanes 1 vs. 4 and 2 vs. 3 .

\subsection{Antigenicity of hordeins}

The antigenicity of hordein polypeptides is illustrated in Figure 5 (but evident in all presented immunoblot assays). An enriched C-hordein preparation with traces of B-hordein polypeptides was injected into the mice (Figure 5, lane 2). MAb's were obtained that react strongly with B- as well as C-hordein (Figure 5, lanes 3-8). There were more and stronger reacting antibodies to B-than C-hordeins (Figures 2 and 5). B and " $X$ " specific antibodies were identified, but only 


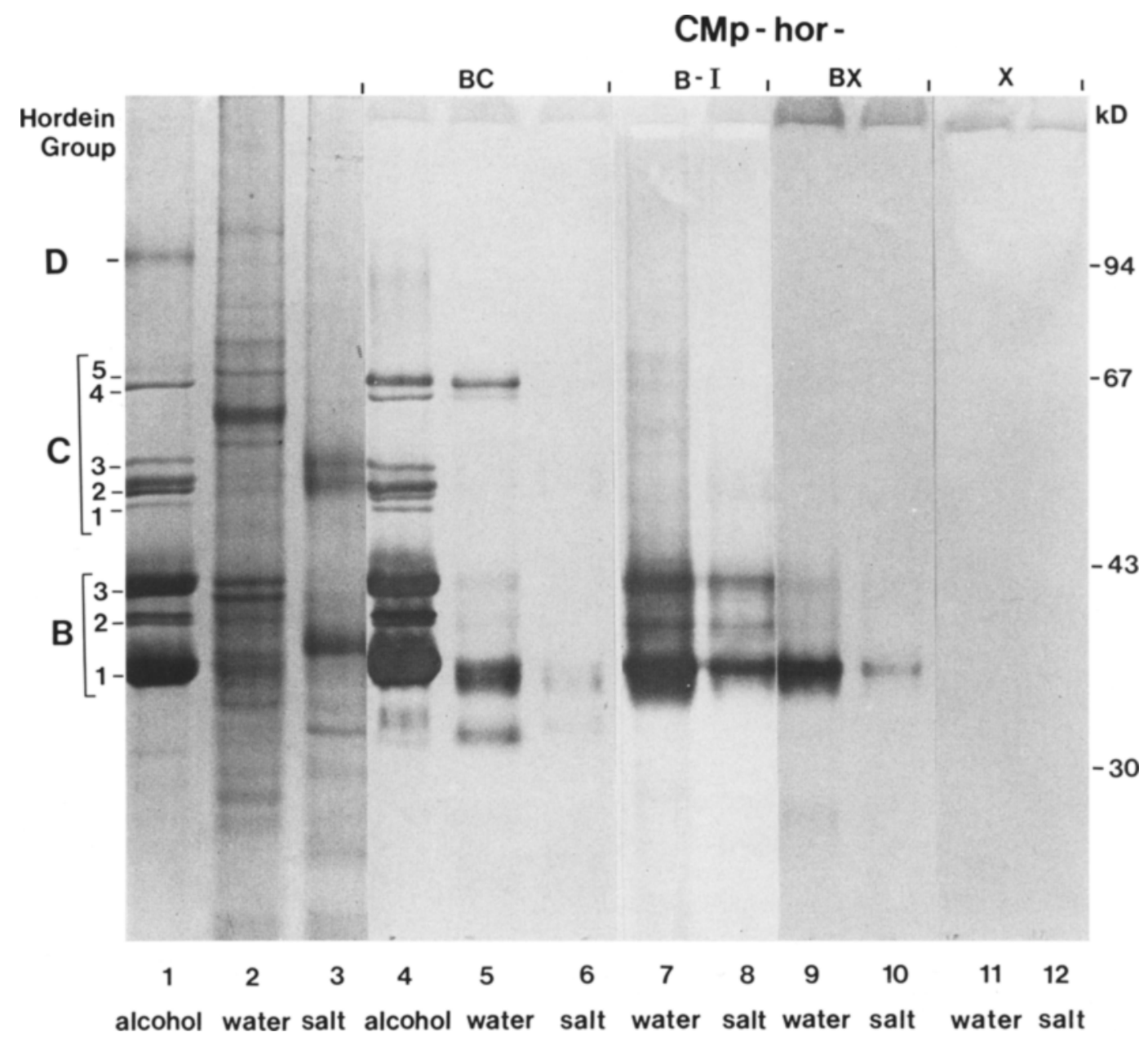

Figure 7a. Water and salt extracts of Bomi barley flour probed with four MAb's to hordeins.

SDS-PAGE patterns from alcohol (total hordein) and water and subsequent salt extraction (lanes 1-3). Immunoblot assays with the various extracts and four different MAb's to hordeins (lanes 4-12).

a weak C-hordein specific antibody, CMpChor (Figure 2, strip 15). The very weak reactions between CMpBXhor and CMpXhor and the enriched C-hordein preparation (Figure 5, lanes 7 and 9) compared with the very strong reaction with the total hordein preparation (Figure 5, lanes 8 and 10) emphasize the strong antigenicity of the B- and " $\mathrm{X}$ "-hordeins.

\subsection{Detection of hordein polymorphism with MAb's}

MAb's can be used to detect and visualize polymorphism within the hordeins as is illustrat- ed in Figure 6 in which total hordein preparations of eight barley cultivars were probed with one or two CMpBChor MAb's in immunoblot assays. Most useful for this purpose are the general specific BC-hordein type antibodies, in which a large number of polypeptides are recognized. Different patterns can also be visualized with different $\mathrm{CMpBChor} \mathrm{MAb's} \mathrm{(Figure} \mathrm{6,}$ lanes 1,2 vs. 3,4$)$.

\subsection{Water and salt extracts of barley flour probed with MAb's to hordeins}

The SDS-PAGE pattern from alcohol, water and subsequent salt extracts of Bomi barley flour 


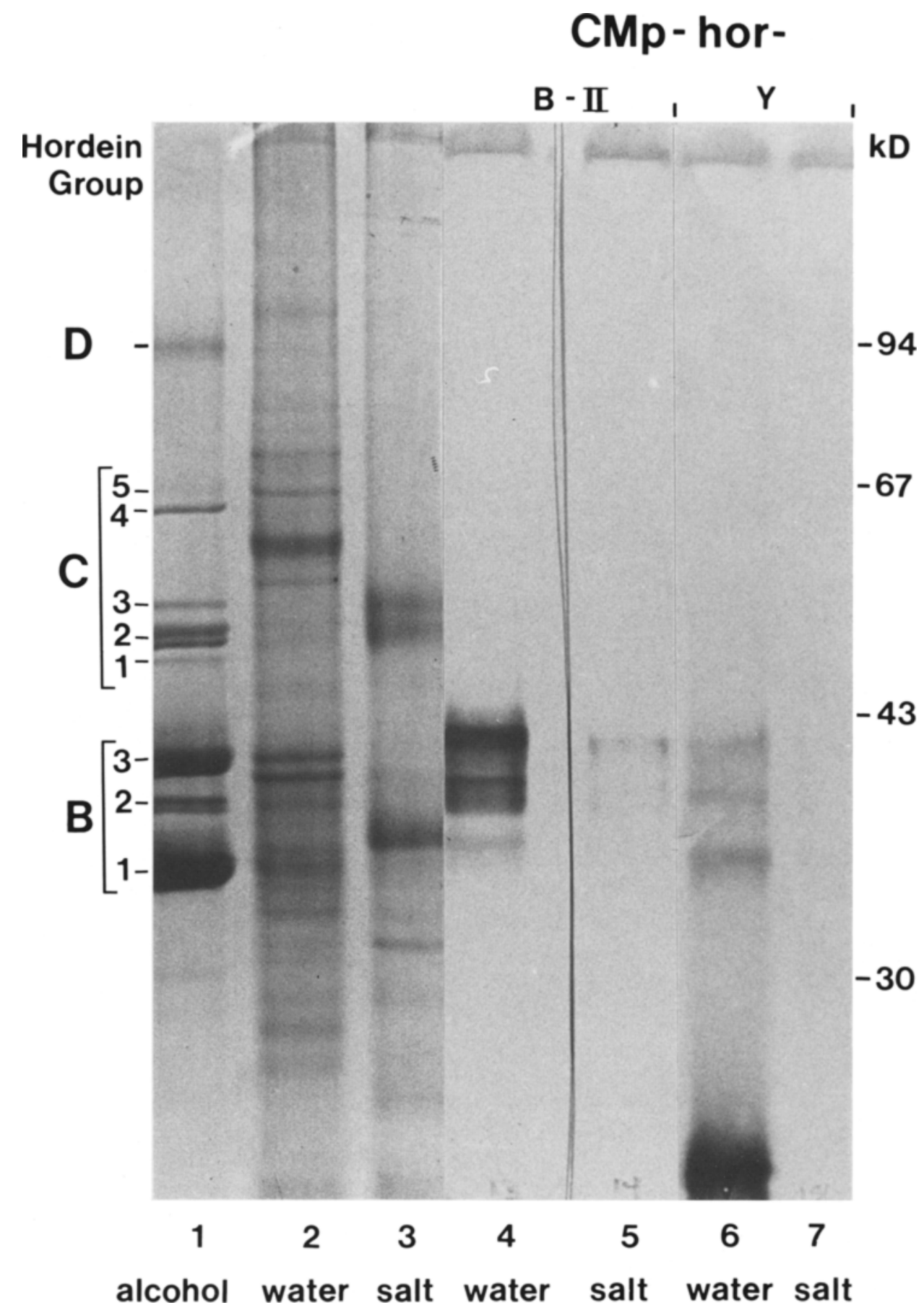

Figure 7b. Water and salt extracts of Bomi barley flour probed with two antibodies to hordeins.

SDS-PAGE patterns from alcohol (total hordein) and water and subsequent salt extraction (lanes 1-3). Immunoblot assays with water and salt extracts and two different antibodies to hordeins (lanes 4-7). 


\section{CMp -hor -}

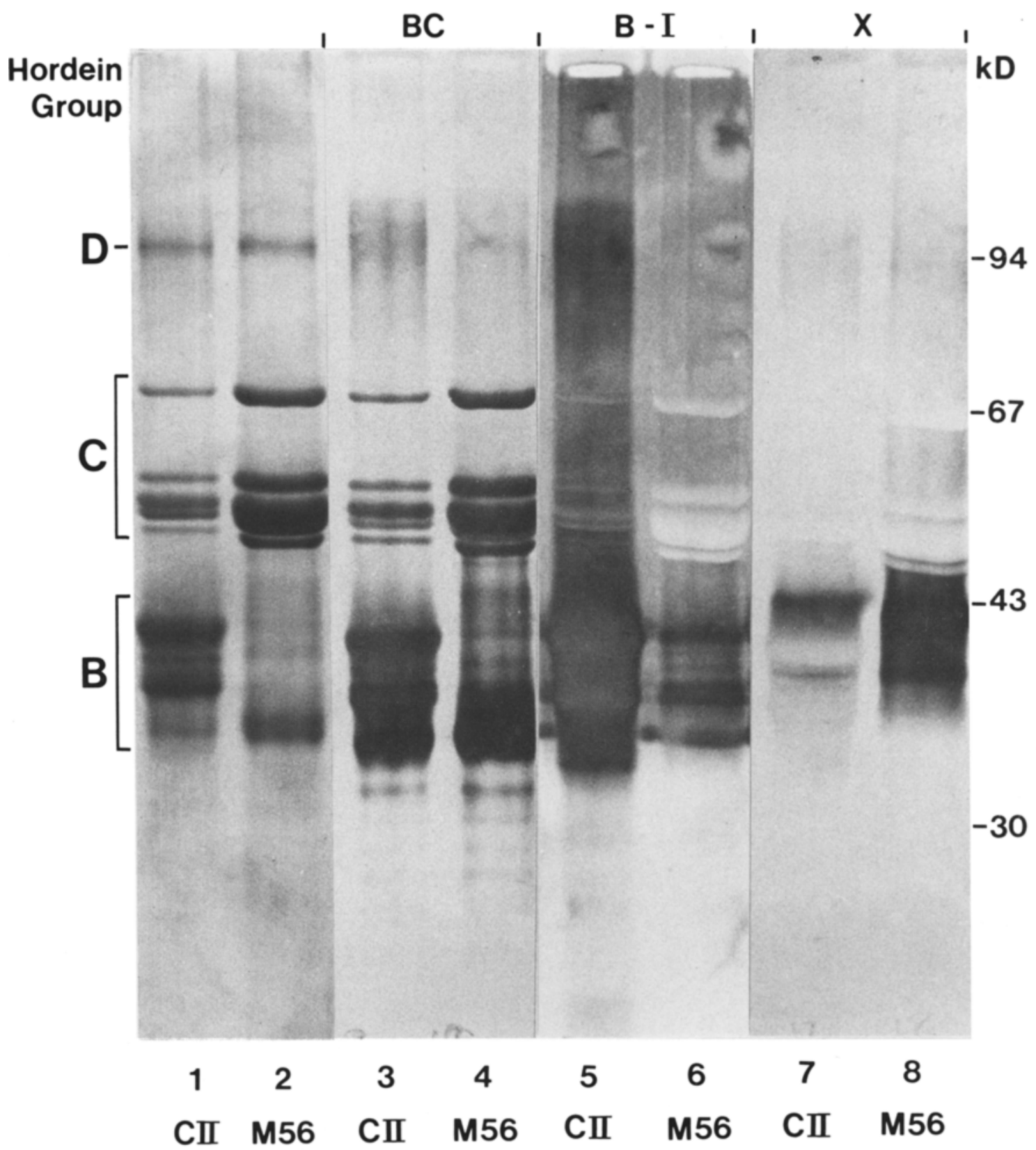

Figure 8a. Immunological comparison of the hordeins of Carlsberg II (CII) and of Risø Mutant 56 (M56).

SDS-PAGE reference gel of total hordein extracts of the two genotypes (lanes 1,2). Immunoblot assays comparing the reaction of total hordein extracts of the two genotypes with four different MAb's to hordeins (lanes 3-8). 


\section{CMp-hor -}

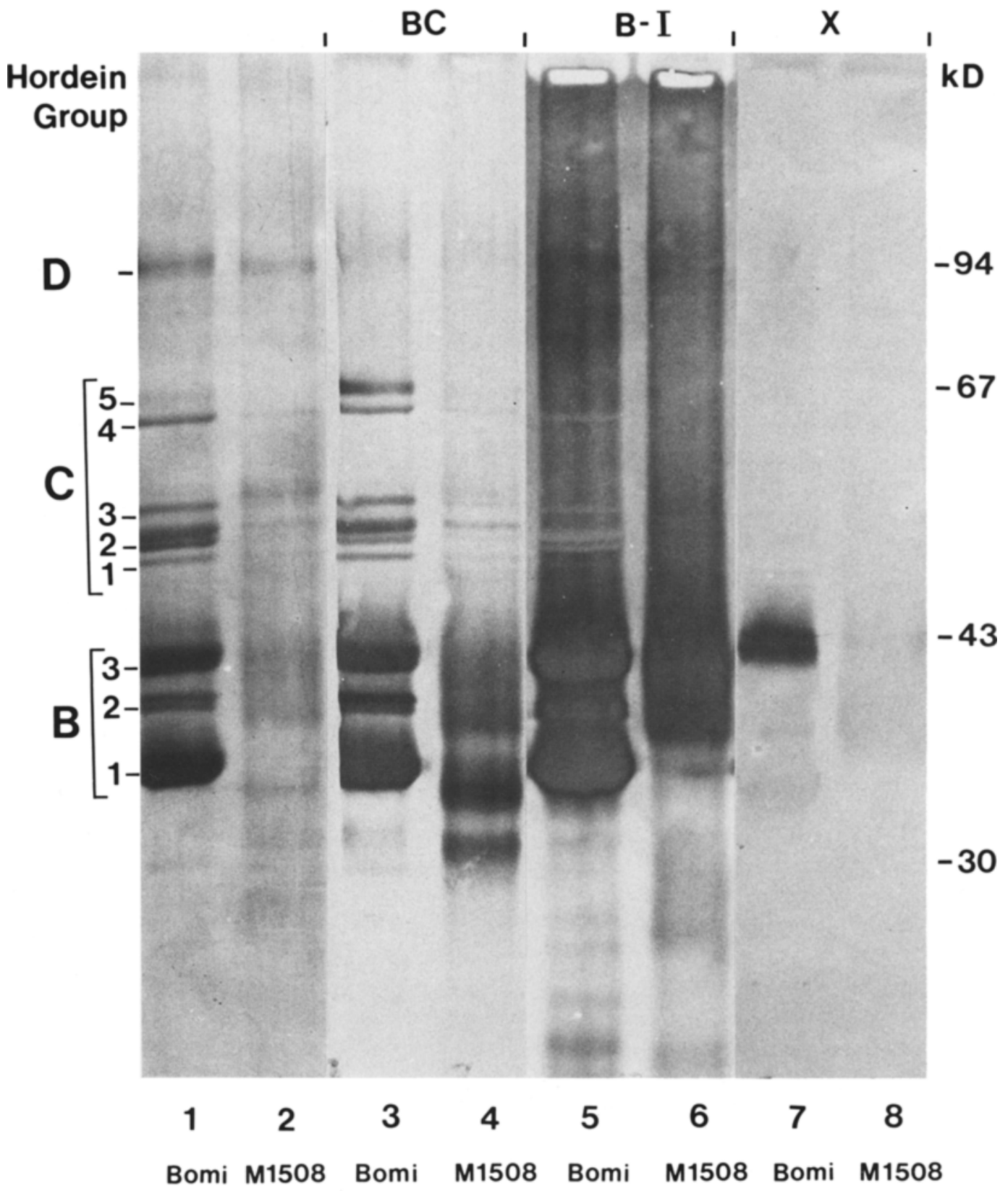

Figure 8b. Immunological comparison of the hordeins of Bomi and Risø Mutant 1508 (M1508).

SDS-PAGE pattern of total hordein extracts of the two genotypes (lanes 1, 2). Immunoblot assays comparing the reaction of total hordein extracts of the two genotypes with three different MAb's to hordein (lanes 3-8). 
are different from each other (Figure $7 a$ and $b$, lanes 1-3). Immunoblotting of the water and salt extracts with the MAb's to hordeins gave reactions with a limited number of polypeptides (Figure 7a, lanes 4-12, 7b, lanes 4-7). The water and salt soluble polypeptides reacting with a particular antibody correspond in mobility to polypeptides also present in the alcohol extract. Clearly, the concentration of the polypeptides is lower in the salt than in water extract (Figure 7a, lanes 5-12 vs. 1,$4 ; 7$ b, lanes $4-7$ vs. 1 ). $\mathrm{CMpBChor}$ reacted with polypeptides corresponding to $\mathrm{C} 5, \mathrm{C} 4, \mathrm{~B} 1$, and one of even lower apparent molecular weight from the water extract (Figure 7a, lane 5). CMpBhorl bound to polypeptides corresponding to B1, B2, and B3 from the water and salt extract (Figure 7a, lanes $7,8)$. CMpBXhor showed only one reacting band in the B1 position (Figure 7a, lanes 9, 10). CMpXhor recognized no water or salt soluble polypeptides (Figure 7a, lanes 11, 12). CMpBhorII recognized polypeptides in the $\mathrm{B} 2$ and B3 hordein position (Figure $7 \mathrm{~b}$, lanes 4,5 ). $\mathrm{CMpYhor}$ showed a strong reaction with the relatively low molecular weight polypeptide from the water extract (Figure 7b, lane 6) corresponding to the polypeptide reacting from the alcohol soluble extract in Figure 2, strip 17. Thus, it appears that the salt and especially water extracts contain traces of B- and C-hordeins. Using the monoclonal antibodies described here we could not detect any common epitopes shared by hordein polypeptides and albumins or globulins.

\subsection{Immunological comparision of the hordeins of Carlsberg II and Risø Mutant 56 and Bomi and Risø Mutant 1508 in immunoblotting and thin sections}

The hordeins of the B-hordein deficient Risø Mutant 56 (M56) and its progenitor cultivar Carlsberg II were probed with four MAb's to hordeins (Figure 8a). The deficiency of Bhordeins in M56 compared to CII can be clearly seen in SDS-PAGE (Figure 8a, lanes 1, 2), and in immunoblot assays of the B-hordein specific CMpBhorI and CMpBChor MAb's (Figure 8a, lanes 3-6). There are polypeptides present in the B-hordein region as evidenced by the reactions with these same antibodies and more evident with $\mathrm{CMpBXhor}$ and $\mathrm{CMpXhor} \mathrm{(Figure} 8 \mathrm{a}$, lanes 7-8). The elevated C-hordein level in M56 can be visualized in the SDS-PAGE as well as by immunoblotting using $\mathrm{CMpBChor} \mathrm{(Figure} \mathrm{8a,}$ lanes 3-4).

Immunoblot assays using extracts of the total hordein deficient Risø Mutant 1508 (M1508) and its progenitor cultivar Bomi showed the hordein deficiency of M1508. It can be seen in the $\mathrm{CMpBCh}$ or and $\mathrm{CMpBhorI}$ patterns (Figure $8 \mathrm{~b}$, lanes 3-6) as well as in the SDS-gel (Figure 8 b, lanes 1,2). However, the sensitivity of the MAb's somewhat masks the comparison. The $\mathrm{CMpBChor}$ reaction does reveal that M1508 is enriched in a polypeptide only slightly detectable in Bomi just below the B 1 band (Figure $8 \mathrm{~b}$, lanes 3,4$)$ and not readily detectable in the SDS-gel (Figure 8, lanes 1, 2). M1508 is devoid of the " $\mathrm{X}$ " polypeptide doublet.

Immunofluorescence resulting from FITC-labelled $\mathrm{CMpBhorI}: 1$ antibodies reacting with endosperm proteins in thin sections of Carlsberg II and Bomi barley kernels compared to the hordein deficient mutants, M56 and M1508 is shown in Figure 9. The immunofluorescence is distributed over the endosperm cells demonstrating that the epitope recognized by $\mathrm{CMpB}$ horI: 1 in the unfolded primary structure of B-hordeins as visualized in immunoblot assays is also recognizable, when the polypeptide has its normal tertiary structure. The B-hordein polypeptides are exclusively localized in the endosperm tissue, whereas the aleurone and embryo tissues do not contain detectable amounts. The mutant endosperms (Figure 9) display a drastic reduction in the immunofluorescence suggesting that new mutants with lower amounts of hordein may be identified by this method.

\section{DISCUSSION}

The fusion described here resulted in 17 hybridoma lines secreting antibodies that recognized epitopes on more than one hordein polypeptide (Figure 2). Cloning by limited dilution to produce monoclonal antibodies did not narrow the specificity of the antibodies. Some antibodies reacted with one or two polypeptides only (CMpXhor, CMpVhor, CMpYhor), where- 


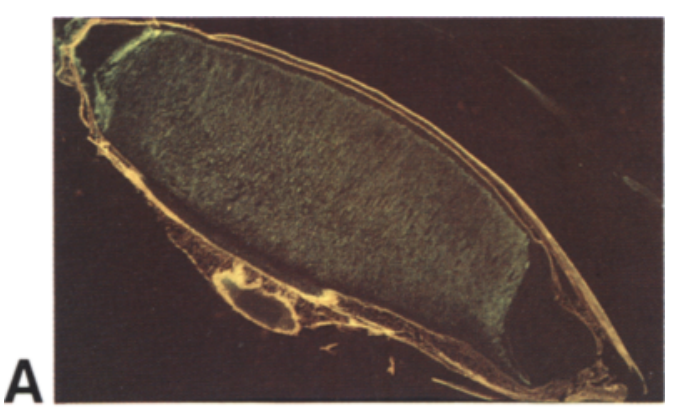

CII

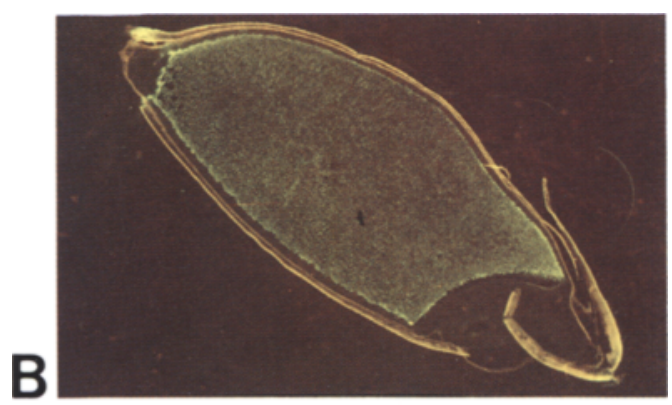

BOMI

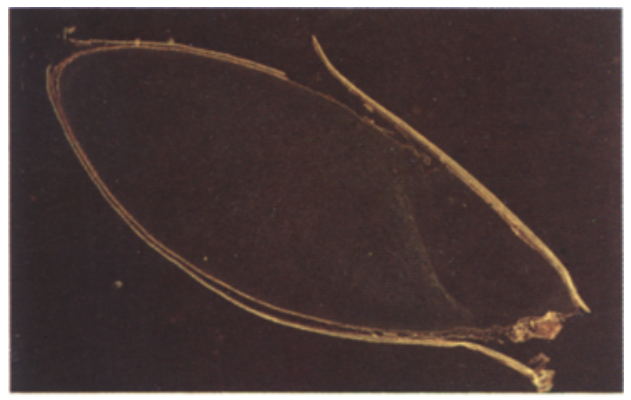

M56

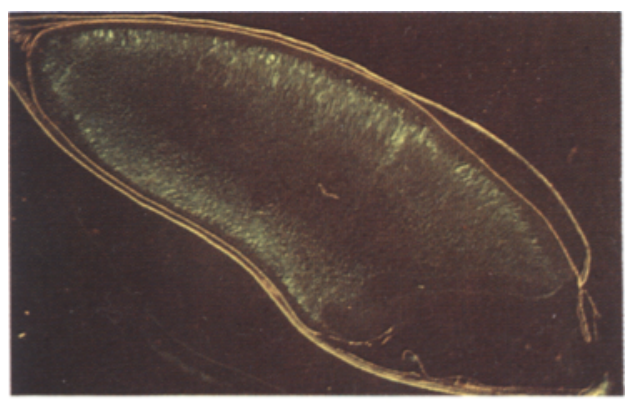

M1508

Figure 9. Immunofluorescence of hordein deficient barley mutants.

Immunofluorescence arising from thin sections of non-fixed mature seeds after incubation with fluorescein isothiocyanate coupled CMpBhorl:1. A: Carlsberg II, M56, B: Bomi, M1508.

as others reacted with essentially all of the $B$ - and C-hordein polypeptides (CMpBChor) (Figure 1).

The recognition of a number of polypeptides by a given MAb gives further evidence for primary structure homology among hordein polypeptide. Employing polyclonal antibodies to hordein polypeptides these homologies have been implicated and homologies among prolamins from different cereal species have been demonstrated $(10,16,17,45)$. The broad specificity within (CMpBhorl) and among (CMpBChor) hordein groups is probably due to the location of the epitopes within repetitive glutamine + proline blocks which are common to the B- and C-hordein polypeptides $(19,37)$. An epitope consists of 6-7 amino acids (1). The isolation of as many as six hybridoma lines secreting antibodies reacting with both $\mathrm{B}$ - and C-hordein polypeptides ( $\mathrm{CMpBChor)} \mathrm{is} \mathrm{also}$ consistent with a high frequency of repetitive amino acid sequences in the primary structure of hordeins. The most intensely reacting $\mathrm{MAb}$ is CMpBhorI (Figures 2,3,5). The epitopes for this MAb may be repeated within as well as among the B-hordein polypeptides but is not present in C-hordein. On the other hand, one antibody, $\mathrm{CMpChor,} \mathrm{recognized} \mathrm{an} \mathrm{epitope} \mathrm{which} \mathrm{is} \mathrm{only}$ found in the C-hordein polypeptides. This result corroborates the finding from peptide mapping $(14,25)$ that B-and C-hordeins are different, but contain homologous peptides. The available information indicates that the B-hordein specific epitopes are localized in the $\mathrm{COOH}-\mathrm{ter}-$ minal part of these polypeptides, whereas the $\mathrm{C}$-hordein specific epitopes are found either in the $25 \mathrm{NH}_{2}$-terminal or in the $11 \mathrm{COOH}$-terminal amino acid stretch.

In general, the hordeins are quite antigenic, but the B-hordeins elicited a stronger antigenic response than the $\mathrm{C}$-hordeins, in spite of the apparent low concentration of B-hordein in the 
enriched $\mathrm{C}$-hordein antigen preparation (Figure 5). The common epitopes, which most likely are localized in the proline-glutamine rich regions, are found in the $\mathrm{NH}_{2}$-terminal third of the B-hordein polypeptide and are thought to make up the major part of the $\mathrm{C}$-hordein polypeptides.

Polypeptides were identified, that were not visualized on SDS-PAGE of the enriched Chordein antigen or in the total hordein preparation. The "X"-polypeptide doublet (CMpXhor, $\mathrm{CMpBXhor)} \mathrm{and} \mathrm{the} \mathrm{relatively} \mathrm{low} \mathrm{molecular}$ weight "Y"-polypeptide (CMpYhor) as well as other polypeptides with apparent moleculâr weight below that of $\mathrm{B} 1$-hordein $(\mathrm{CMpBChor}$, CMpBhorI, CMpBXhor) were detected (Figures 2 and 5).

A CMpXhor antibody reacts with a polypeptide doublet of apparent molecular weight of 43 $\mathrm{kD}$. The doublet is not visible in Coomassiestained SDS-gels of alcohol, water, or salt extracts of barley kernels (but migrates to just above the B3 polypeptide of Bomi), nor is it visible in immunoblot assays of water and salt extracts (Figure 7a). However, it does have a common epitope with some of the B-hordeins as evidenced by CMpBXhor, but not with $\mathrm{CMpBChor}$ or $\mathrm{CMpBhorl}$ (Figures 3, 1a, 8a). The fact that M56 reacts very strongly with CMpXhor (Figure 8A, lane 9) eliminates the possibility that " $\mathrm{X}$ "-polypeptides belong to the B-hordeins since this mutant has a deletion in the Hor-2 locus (31). Another uncharacterized polypeptide is "Y". A CMpYhor antibody reacts with this relatively low molecular weight polypeptide and possibly some B-hordein polypeptides (Figures 2 and $7 \mathrm{~b}$ ). This polypeptide was found predominantly in the water extract but was not present in the salt extract (Figure 7b). The intensity of the CMpYhor reaction was usually low with polypeptides of alcohol extracts. Therefore, it is likely that the "Y"-polypeptide is an albumin that is also alcohol soluble. With this exception it appears that the MAb's obtained in this study do not recognize epitopes on water (albumin) or salt (globulin) soluble polypeptides (Figure 7). However, the salt and especially water extracts contain traces of the alcohol soluble hordeins. The $\mathrm{C}$-hordeins have been found as monomers, whereas B-hordeins may be present either as monomers or in aggregates (18). This would imply that cystein poor C-hordeins and the cystein rich B-hordeins, which have not formed inter-disulphide bridges are partially extractable with water. These water soluble hordein polypeptides are not visualized on Coomassiestained SDS-gels of water and salt extracts, but are easily detected in immunoblot assays (Figure 7), demonstrating the sensitivity of the method.

Hordein polymorphism can be detected in immunoblot assays using MAb's (Figure 6). Especially useful are the CMpBChor MAb's with their broad specificity. Immunoblot assay using monoclonal antibodies is more sensitive than SDS-PAGE alone and in addition polypeptides not stainable with Coomassie blue can be detected (48). This makes immunoblot assays with MAb's to hordein a new tool for genotype identification, which with the proper MAb is more sensitive than SDS-PAGE alone (46).

Whereas Risø Mutant 56 is nearly devoid of B-hordeins compared to the progenitor cultivar Carlsberg II, there are polypeptides in the B region (Figure $8 \mathrm{a}$ ) including the " $\mathrm{X}$ " doublet recognized by $\mathrm{CMpXhor} \mathrm{and} \mathrm{other} \mathrm{polypep-}$ tides recognized by $\mathrm{CMpBChor,} \mathrm{CMpBhorl}$, and $\mathrm{CMpBXhor}$. Some of these other polypeptides could be the $\gamma$-type hordeins described by SHEWRY et al. (44). It is therefore likely that the $\gamma$-hordeins share common epitopes with Bhordeins.

The mutants, M56 and M1508 were also used to test an immunological screening method utilizing fluorescein isothiocyanate labelled CMpBhorI. The immunofluorescence was significatly greater from CII and Bomi than from M56 and M1508 kernels in thin sections reacted with CMpBhorI. This would be a convenient method for screening new mutants low in hordein polypeptides (38). A number of different strategies have been proposed to modify barley protein quantity and quality $(6,12,34$, 49). The low lysine hordeins may be replaced with other storage proteins of higher lysine content $(12,49)$, e.g. with protein $Z(23)$, $\beta$-amylase, chymotrypsin inhibitor 1 and $2(3,24,38)$. Therefore, with the aid of monoclonal antibodies raised against these different groups of endosperm polypeptides, it should be possible with the non-destructive immunofluorescence detec- 
tion method (38) to screen a large number of seeds for identification of new mutants with the desired protein composition. This can provide new genes for breeding programmes intended to produce high yielding high lysine varieties.

\section{ACKNOWLEDGEMENTS}

The authors wish to thank Professor DITER VON WETTSTEIN for advice and helpful discussions. TOM BEKTVED for excellent technical assistance, Hanne Nielsen, Lise Trillot, Nina RASMUSSEN and ANN-SOFI STEINHOLTZ for manuscript and figure preparation. The work was financially supported by the Biotechnological Action Rrogramme of the Commission of the European Communities with contract no. BAP009 I-DK (B) to Mr. H.G. SARX and Professor D. VON WETTSTEIN.

\section{REFERENCES}

1. ATASSI, M. Z: Molecular immune recognition of proteins: The precise determination of protein antigenic sites had led to synthesis of antibody combining sites and other types of protein binding sites. In: Structure and variation in influenza virus. Laver/Air eds. Elsevier, North Holland Inc, pp. 241-27l (1980)

2. Blake. T.K., S. E. Ullrich \& R. A. Nilan: Mapping of Hor-3 locus encoding $D$ hordein in barley. Theor. Appl. Genet. 63, 367-371 (1982)

3. Boisen, S., C. Y. ANdersen \& J. HejgaARd: Inhibitory of chymotrypsin and microbial serine proteases in barley grains. Isolation, partial characterization and immunochemical relationships of multiple molecular forms. Physiol. Plant. 52, 167176 (1981)

4. BRANDT, A: Endosperm protein formation during kernel development of wild type and a high-lysine barley mutant. Cereal Chem. 53, 890-901 (1976)

5. Brandt, A.,A. Montembault, V.Cameron-Mills \& S. K. Rasmussen: Primaty structure of a B1 hordein gene from barley. Carlsberg Res. Commun. 50, 333-345 (1985)

6. BRIGHT, S. W. J., B. J. Miflin \& S. E. Rognes: Threonine accumulation in the seeds of a barley mutant with an altered aspartate kinase. Biochem. Genet. 20, 229-243 (1982)

7. Cameron-Mills, V.: Structure and composition of protein bodies purified from barley endosperm by silica sol density gradients. Carlsberg Res. Commun. 45, 557-576 (1980)
8. Cameron-Mills, V. \& D. von Wettstein: Protein body formation in the developing barley endosperm. Carlsberg Res. Commun. 45, 577-594 (1980)

9. ChuA, N.-H.\& P. Bennoun: Thylakoid membrane polypeptides of Chlamydomonas reinhardtii: Wild-type and mutant strains deficient in photosystem Il reaction center. Proc. Nat. Acad. Sci., USA, 72, 2175-2179 (1975)

10. Dierks-Ventling, C. \& K. COzens: Immunochemical cross-reactivity between zein, hordein and gliadin. FEBS lett. 142, 147-150 (1982)

11. DoLl, H.: A nearly non-functional mutant allele of the storage protein locus Hor 2 in barley. Hereditas 93, 217-222 (1980)

12. DoLl. H.: Nutritional aspects of cereal proteins and approaches to overcome their deficiencies. Phil. Trans R. Soc. Lond. B. 304, 373-380 (1984)

13. DOLL, H. \& A. H. D. Brown: Hordein variation in wild (Hordeum spontaneum) and cultivated $(\mathrm{H}$. vulgare) barley. Can. J. Genet. Cytol. 21, 391-404 (1979)

14. Faulks, A. J., P. R. Shwery \& B. J. Miflin: The polymorphism and structural homology of storage polypeptides (hordein) coded by the Hor-2 locus in barley (Hordeum vulgare L. ). Biochem. Genet. 19 , 841-858 (1981)

15. Fazekas de St. Groth, S. \& D. Scheidegger: Production of monoclonal antibodies: Strategy and Tactics. J. Immunol. Meth. 35, 1-21 (1980)

16. FESTENSTEIn, G. N. \& F. C. HAY: Immunochemical studies on barley seed storage proteins. Plant Sci. Lett. 26, 199-209 (1982)

17. Festenstein, G. N., F. C. Hay, B. J. Miflin \& P. R. SHEWRY: Immunochemical studies on barley seed storage proteins. Planta 162, 524-531 (1984)

18. Field, J. M., P. R. Shewry \& B. J. Miflin: Aggregation status of alcohol soluble storage proteins of barley, rye, wheat and maize. J. Sci. Food Agric. 37, 262-269 (1983)

19. Forde, B. G., M. Kreis, M. S. Williamsen, R. P. Fry, J. Rywell, P. R. SHEWRy, N. BUNCE AND B. J. MIFLIN: Short tandam repeats shared by $B-$ and C-hordein cDNAssuggest a common evolutionary origin for two groups of cereal storage protein genes. EMBO J. 4, 9-15 (1985)

20. Forde, B. G., A. Heyworth, J. Pywell \& M. Kreis: Nucleotide sequence of a $B 1$ hordein gene and the identification of possible upstream regulatory elements in endosperm storage protein genes from barley, wheat and maize. Nucl. Acid. Res. 13, 7327-7339 (1985)

21. GIESE. H. \& H. E. HOPP: Influence of nitrogen nutrition on the amount of hordein, protein $Z$ and $\beta$-amylase messenger RNA in developing en- 
dosperms of barley. Carlsberg Res. Commun. 49, 365-383 (1984)

22. Graham, R. C. JR., V. Lundholm \& M. J. KARNOVSKY: Cytochemical demonstration of peroxidase activity with 3-amino-9-ethylcarbazole. J. Histochem. Cytochem. 13, 150-153 (1965)

23. Hejgaard, J:: Purification and properties of protein $\mathrm{Z}$ - a major albumin of barley endosperm. Physiol. Plant. 54, 174-182 (1982)

24. HeJgAaRd, J. \& S. BoISEN: High-lysine proteins in Hiproly barley breeding: Identification, nutritional significance and new screening methods. Hereditas 93, 311-320 (1980)

25. Holder, A. A. \& J. INGVERSEN: Peptide mapping of the major components of in vitro synthesized barley hordein. Evidence of structural homology. Carlsberg Res. Commun. 43, 177-184 (1978)

26. HønBerg, L. S.: Probing barley mutants with a monoclonal antibody to a polypeptide involved in photosynthetic oxygen evolution. Carlsberg Res. Commun. 49, 703-719 (1984)

27. Høyer-Hansen, G.: Monoclonal antibodies to chlorophyll $\mathrm{a}_{\mathrm{a}}$-protein 1 in barley. In: Advances in Photosynthesis Research, C. Sybesma ed. M. Nijhoff/Dr. W. Junk Publishers, The Hague, Netherlands, Vol III, pp. 171-174 (1984)

28. Høyer-Hansen, G., L. S. HønberG \& P. B. Høu: Probing in vitro translation products with monoclonal antibodies to a $15.2 \mathrm{kD}$ polypeptide subunit of photosystem I. Carlsberg Res. Commun. 50, 211-221 (1985)

29. Ingversen, J., B. KøIE \& H. DOLl: Induced seed protein mutant of barley. Experientia 29, 11511152 (1973)

30. Ingversen, J., A. Brandt \& V. Cameron-Mills: The structure, biosynthesis and intracellular transport of barley endosperm reserve proteins. Abhdlg. Akad. Wiss. DDR, Abt. Math., Naturwiss., Techn. No. SN, 41-56 (1981)

31. Kreis, M., P. R. SHEWRy, B. G. Forde, S. Rahman \& B. J. MifLiN: Molecular analysis of a mutation conferring the high-lysine phenotype on the grain of barley (Hordeum vulgare). Cell 34, 161-167 (1983)

32. KREIS, M.,P. R. Shewry, B. G. Forde \& B. J. MifLIN: In: Oxford Surveys of Plant Cell and Molecular Biology. Vol. 2 (B. J. Miflin, ed.) Oxford University Press, Oxford (1985) pp. 253-317

33. KøIE, B. \& H. Doll: Protein and carbohydrate components in the Risø highlysine barley mutants. In: Seeds Protein Improvement in Cereals and Grain Legumes I, 205-215, IAEA Vienna (1979)

34. Miflin, B.J., S. W. J. BRIGHT \& E. ThOMAS: Towards the genetic manipulation of barley. Proc. Fourth
Intern. Barley Genet. Symp. Edinburgh (1981) pp. 919-926

35. Oram, R. N., H. Doll \& B. KoIE: Genetics of two storage protein variants in barley. Hereditas 80 , 53-58 (1975)

36. Rasmussen, S. K., H. E. HopP \& A. BrandT: Nucleotide sequences of cDNA clones for $\mathrm{B} 1$ hordein polypeptides. Carlsberg Res. Commun. 48, 187 199 (1983)

37. Rasmussen, S. K. \& A. Brandt: Nucleotide sequences of CDNA clones for C-hordein polypeptides. Carlsberg Res. Commun. 51, 371-379 (1986)

38. RASMUSSEN, U.: Immunological screening for specific protein content in barley seeds. Carlsberg Res. Commun. 50, 83-93 (1985)

39. RASMUSSEN, U.: Immunofluorescence applied for detection of specific proteins in barley seeds. In: Modern Methods of Plant Analysis vol VII, ed. H. F. Linskens \& J. F. Jackson, Springer Verlag (in preparation)

40. SCHmitT, J. M.: Purification of hordein polypeptides by column chromatography using volatile solvents. Carlsberg Res. Commun. 44, $431-438$ (1979)

41. Schreier, M., G. Köhler, H. Hengartner. C. Berek, T. Trucco, L. Forni, T. Staehelin, J. Stocker \& B. TAKaCs: Hybridoma Techniques EMBO, SKMB Course 1980, Basel

42. Shewry, P. R., A. J. Faulks, R. A. Pickering, I. T. Jones, R. A. Finch \& B. J. Miflin: The genetic control of barley storage proteins. Heredity 44 , 383-389 (1980)

43. Shewry, P. R., R. A. Finch, S. Parmar, J. Franklin \& B. J. MifLIN: Chromosomal location of Hor3, a new locus covering storage proteins in barley. Heredity 50, 179-189 (1983)

44. Shewry, P. R., M. Kreis, S. Parmar, C. J. -L. LeW \& D. D. KASARDA: Identification of $\gamma$-type hordeins in barley. FEBS Lett. 190, 61-64 (1985)

45. Skerritt, J. H., R. A. Smith, C. W. Wrigley \& P. A. UNDERWOOD: Monoclonal antibodies to gliadin proteins used to examine cereal grain protein homologies. J. Cereal Sci. 2, 215-224 (1984)

46. SMith, D.B., P. R. Lister \& P. R. HANSON: Discrimination of barley varieties by electrophoresis of endosperm proteins extractable into a mixture of sodium dodecyl sulphate, 2-mercaptoethanol and dimethylformamide. J. Cereal Sci. 4, 107-116 (1986)

47. Towbin, H., T. Staehelin \& J. Gordon: Electrophoretic transfer of proteins from polyacrylamide gels to nitrocellulose sheets: Procedure and some applications. Proc. Nat. Acad. Sci., USA 76, 4350-4354 (1979) 
48. Ullrich, S. E., G. Høyer-Hansen \& U. RasMUSSEN: Monoclonal antibodies in the characterization of hordeins and barley quality improvement. In: Barley Genetics V: Proceedings 5th Int. Barley Genet. Sym., Okayama, Japan 1986 (in press)

49. WetTSTEIN, D. von: Genetic engineering in the adaption of plants to evolving human needs. Experienta 39, 687-713 (1983)

Accepted by E. LUND 